\title{
KUALITAS HIDUP LANSIA DITINJAU DARI SABAR DAN DUKUNGAN SOSIAL
}

\author{
Devi Maya Puspita Sari ${ }^{1}$, Canina Yustisia Dwi Lestari², \\ Evan Chairul Putra ${ }^{3}$, Fuad Nashori ${ }^{4}$ \\ 1,2,3,4 Magister Psikologi, Universitas Islam Indonesia \\ 1,2,3,417915038@students.uii.ac.id
}

\begin{abstract}
Abstrak. Lanjut usia merupakan salah satu masa perkembangan yang ditandai dengan menurunnya fungsi fisik, psikologis, dan sosial. Penurunan fungsi tersebut dapat menurunkan kualitas hidup lansia. Untuk meningkatkan kualitas hidup lansia, diperlukan sebuah dukungan sosial dan strategi koping dalam menghadapi perubahan yang terjadi. Strategi koping yang dapat digunakan adalah sabar. Penelitian ini bertujuan untuk mengetahui korelasi antara sabar dan dukungan sosial terhadap kualitas hidup lansia di Yogyakarta. Subjek penelitian berjumlah 24 laki-laki dan 34 perempuan yang diperoleh dengan purposive sampling. Data yang dikumpulkan menggunakan The World Health Organization Quality of Life (WHOQOL) skala sabar, dan Multidimensional Scale of Perceived Social Support (MSPSS). Analisis data menggunakan analisis regresi berganda dan korelasi pearson. Hasil analisis menunjukkan bahwa sabar dan dukungan sosial berkorelasi positif dengan kualitas hidup lansia. Dengan kata lain, kualitas hidup dapat diprediksi berdasarkan kesabaran dan dukungan sosial.
\end{abstract}

Kata kunci: kualitas hidup, sabar, dukungan sosial, lansia

Abstrack. Elderly is one of development periods characterized by physical, psychological, and social degeneration that can decrease the quality of life. Quality of life can be improved by social support and sabr as a coping strategy to overcome the problems that occur in elderly periods. This research aimed to analyze the correlation between sabr and social support with quality of life of elders in Yogyakarta. The number of subjects is 24 men and 34 women which is chosen by purposive sampling. Data was collected by The World Health Organization Quality of Life (WHOQOL), patience instrument, and Multidimensional Scale of Perceived Social Support (MSPSS). Multiple linear regression was used to analyze multivariate correlation and pearson correlation was used to analyze the bivariate correlation. This suggest that there was a significant positive correlation between sabr, social support and quality of life of elders. In the other words, quality of life can be predicted based on sabr and social support.

Keyword : Quality of life, Patience, Social Support, Elderly 
Usia tua atau lanjut usia merupakan periode terakhir dalam rentang kehidupan manusia. Hurlock (2006) menyatakan bahwa masa lansia merupakan periode kemunduran atau penurunan fungsi fisik, psikologis, dan sosial. Laju penurunan fungsi-fungsi tersebut dipengaruhi oleh cara lansia dalam mengatasi permasalahan hidup yang dialami dan penurunan fungsi tersebut memungkinkan terjadinya harapan hidup lansia menjadi rendah.

Indonesia merupakan salah satu negara yang akan memasuki era penduduk menua karena jumlah penduduk lansia pada tahun 2015 melebihi angka 7 persen, yaitu sebesar 8,49 persen (21,68 juta jiwa). Jumlah penduduk lansia diprediksi akan terus mengalami peningkatan, yaitu pada tahun 2020 akan menjadi 27,08 juta jiwa, pada tahun 2025 sebesar 33,69 juta jiwa, pada tahun 2030 sebesar 40,95 juta jiwa dan 48,19 juta jiwa pada tahun 2035. Persentase lansia terbesar pada tahun 2015 berada di DI Yogyakarta sebesar 13,46 \%, Jawa Tengah sebesar 11,67 \% dan Jawa Timur sebesar 11,46 \%. (Badan Pusat Statistik, 2016).

Proses menua yang dialami setiap individu dapat menyebabkan terjadinya berbagai masalah, baik fisik, psikologis, maupun sosial. Ferucci dan Koh (Santrock, 2010) mengungkapkan bahwa secara fisik, bertambahnya usia meningkatkan kemungkinan munculnya penyakit atau keadaan sakit. Semakin bertambah tua usia individu, persentase penduduk lansia yang mengalami keluhan kesehatan semakin besar dan rata-rata lama sakitnya semakin meningkat, yaitu dalam sebulan terakhir pada tahun 2015, jumlah keluhan kesehatan sebesar 37,47 \%untuk pra lansia, 48,30 \% untuk lansia muda, 55,11\% untuk lansia madya dan 57,96 \% untuk lansia tua (Badan Pusat Statistik, 2016).

Perubahan secara fisik membuat lansia merasa lemah, tidak berdaya, dan tidak berharga. Selain itu, perubahan kondisi sosial, seperti kehilangan pekerjaan, kehilangan pasangan, tinggal terpisah dari anak-anak juga menimbulkan masalah pada lansia. Hal ini dikarenakan perubahan yang terjadi pada lansia cenderung akan mengarah pada penyesuaian diri yang buruk dan ketidakbahagiaan dalam hidup (Hurlock, 2006). Rendahnya tingkat kesehatan, ketidakmampuan lansia dalam menjalani hidup, kehilangan pasangan, dan rendahnya dukungan sosial menyebabkan lansia mengalami depresi (Lee \& Park, 2008; Ng \& dkk, 2010, dalam Santrock, 2010). Ketidakbahagiaan dan depresi yang dirasakan oleh lansia berpengaruh terhadap kualitas hidup yang dimilikinya.

Kualitas hidup merupakan konsep multidimensional yang menunjukkan kepuasan dan kesejahteraan hidup secara keseluruhan (Abeles, Gift, \& Ory, 1994). World Health Organization (WHO) mendefinisikan kualitas hidup sebagai persepsi individu terhadap kedudukannya dalam konteks sistem budaya dan nilai di masyarakat dan berkaitan dengan tujuan, harapan, standar dan hal yang menjadi perhatiannya. Kualitas hidup dipengaruhi oleh kesehatan fisik, keadaan psikologis, tingkat kemandirian, hubungan sosial, dan hubungan dengan aspek penting dalam lingkungan (Bowling, 2003). Kualitas hidup merupakan hal yang penting dalam kehidupan lansia, yaitu meningkatkan harapan hidup lansia. Sarafino dan Smith (2011) mengungkapkan bahwa kualitas hidup membuat individu tidak mudah sakit dan mempercepat proses kesembuhan serta menjadi pertimbangan yang penting dalam usaha pencegahan munculnya penyakit, baik sebelum maupun sesudah rasa sakit itu dirasakan. Menjaga kualitas hidup merupakan usaha untuk 
menjaga kesehatan, membantu lansia sembuh dengan cepat, dan mengurangi dampak negatif dari penyakitnya.

Hasil wawancara yang dilakukan pada tiga orang lansia perempuan yang berusia 60 dan 75 tahun, menunjukkan bahwa subjek pertama (usia 60 tahun) mengeluh karena keterbatasannya dalam melakukan aktivitas sehari-hari dan merasa sedih karena anakanaknya tinggal di tempat yang jauh. Berbeda halnya dengan subjek kedua (usia 60 tahun) yang mengungkapkan bahwa di usianya saat ini masih tetap menjaga kesehatan badan dengan cara setiap pagi hari melakukan olahraga seperti jalan kaki. Subjek tersebut juga sering mengikuti kegiatan pengajian untuk lebih memahami mengenai agama dan dapat berbagi pengalaman hidup dengan ibu-ibu lainnya. Subjek ketiga (usia 75 tahun) mengungkapkan bahwa meskipun dirinya sudah berusia lanjut, namun tetap menjaga silaturahmi kepada orang lain dengan mengikuti kegiatan masyarakat dan pengajian. Subjek juga mengungkapkan dirinya masih menjaga pola makan yang baik karena menginginkan kondisi badan yang baik meski sudah lanjut usia.

Kualitas hidup yang dimiliki setiap lansia berbeda. Hal ini dikarenakan kualitas hidup mengimplikasikan tingkat keunggulan suatu karakteristik, dimana setiap individu dapat menilai berbeda setiap bagian kehidupannya, sehingga kualitas hidup dapat berbeda pada individu yang berbeda (Bowling, 2003). Salah satu faktor yang mempengaruhi kualitas hidup adalah kondisi psikologis. Erickson mengungkapkan bahwa usia lanjut ditandai dengan adanya integritas ego atau kepuasan (Hurlock, 2006). Integritas digambarkan sebagai suatu keadaan yang dicapai individu setelah berhasil menyesuaikan diri dengan berbagai keberhasilan dan kegagalan dalam kehidupannya. Jika lansia tidak mencapai integritas, maka lansia akan berputus asa dalam menghadapi perubahan dalam kehidupannya, merasa bahwa kehidupan ini tidak berarti dan mengalami keputusasaan berkenaan dengan menjelang kematian, yaitu merasa bahwa ajal sudah dekat dan takut akan kematian (Desmita, 2010). Lansia juga mengalami perasaan rendah diri apabila dibandingkan dengan individu yang lebih muda, sehingga hal ini membuat lansia menjadi cemas, merasa gugup, sering takut, sedih, stres dan cenderung depresi (Rohmah, Purwaningsih, \& Bariyah, 2012). Oleh karena itu, diperlukan suatu strategi untuk menghadapi dan mengatasi berbagai permasalahan dan perubahan hidup yang dialami lansia yang dikenal dengan strategi koping.

Sarafino dan Smith (2011) menyatakan bahwa koping merupakan sebuah proses yang dilakukan individu untuk mengelola kesenjangan antara tuntutan dan kemampuan yang dimiliki dalam situasi yang penuh tekanan. Islam merupakan sebuah agama yang sempurna, di dalamnya terdapat berbagai petunjuk bagi manusia untuk menjalani kehidupannya, begitu pula terkait menghadapi permasalahan hidup, sebagaimana firman Allah dalam surat Al-Baqarah ayat 45, yang artinya, "Mintalah pertolongan dengan sabar dan shalat." Rasulullah shallallahu 'alaihi wasallam juga bersabda,

"Sungguh menakjubkan urusan seorang mukmin, semua urusannya adalah baik baginya.Hal ini tidak didapatkan kecuali pada diri seorang mukmin. Apabila mendapatkan kesenangan, dia bersyukur, maka yang demikian itu merupakan kebaikan baginya. Sebaliknya, apabila tertimpa kesusahan, dia pun bersabar, maka yang demikian itu merupakan kebaikan baginya." (HR. Muslim). 
Berdasarkan sabda Rasulullah di atas, dapat diketahui bahwa sabar merupakan salah satu cara untuk menghadapi permasalahan, sebagaimana yang diungkapkan oleh Al-Jauziyah (2006) bahwa sabar adalah mengumpulkan semua kekuatan untuk dapat menyelesaikan kegelisahan dan permasalahan yang dialami. Lansia yang menyadari hakekat hidupnya sebagai hamba Allah SWT tidak akan merasa putus asa dan menyesal terhadap kehidupannya karena segala hal yang terjadi di kehidupannya, baik di masa lalu, masa sekarang, maupun di masa yang akan datang adalah atas kehendak Allah SWT. Hal ini merupakan bentuk dari sabar terhadap takdir Allah SWT. Kesabaran dapat membuat lansia menjadi lebih optimis dalam menjalani hidup karena orang yang bersabar akan meraih kemenangan, seperti firman Allah SWT dalam surat Ali 'Imron ayat 200, yang artinya,

"Wahai orang-orang yang beriman! Sabarlah, kuatkanlah kesabaranmu, ribathlah (berjaga-jaga di wilayah perbatasan) dan bertakwalah kepada Allah, agar kalian mendapatkan kemenangan"

Strategi koping yang tepat dalam menghadapi masalah, salah satunya dengan bersabar dapat meningkatkan kualitas hidup. Hal ini sesuai dengan Rubbyana (2012) yang menyatakan bahwa strategi koping berhubungan secara positif dengan kualitas hidup. Lansia yang mampu mengubah situasi stres yang dirasakan akibat perubahan-perubahan yang dialami akan mampu menyesuaikan diri dengan berbagai perubahan tersebut, sehingga kualitas hidupnya menjadi baik.

Faktor lain yang dapat mempengaruhi kualitas hidup adalah hubungan sosial. Hubungan sosial meliputi hubungan antara lansia dengan keluarga maupun lingkungan sosialnya. Hurlock (2006) menunjukkan bahwa kepuasan hubungan antara lansia dengan anaknya mengalami penurunan. Hal ini berkaitan dengan ketidakbahagiaan yang dirasakan lansia karena merasa diabaikan oleh anak-anak atau anggota keluarga lainnya yang tinggal berjauhan, padahal dukungan sosial dari orang-orang terdekat membuat lansia dapat menikmati masa tua dengan bahagia dan meningkatkan kualitas hidupnya.

Dukungan sosial merupakan keberadaan orang lain yang dapat diandalkan untuk memberi bantuan, semangat, penerimaan dan perhatian, sehingga dapat meningkatkan kesejahteraan atau kualitas hidup bagi individu yang bersangkutan (Jhonson \& Jhonson, 1991). Hal ini juga diungkapkan oleh Antari, Saktika, dan Ferianto (2016) bahwa dukungan sosial yang diperoleh oleh lansia berhubungan dengan kualitas hidup yang dimilikinya. Sarafino dan Smith (2011) menjelaskan bahwa dukungan sosial dapat berasal dari orang-orang di sekitar individu seperti keluarga, teman dekat dan rekan atau teman sebaya. Dukungan sosial yang dimaksud yaitu dukungan yang dapat meningkatkan kualitas hidup lansia, yang meliputi adanya komponen-komponen dari dukungan sosial itu sendiri, seperti kerekatan emosional, integrasi sosial, adanya pengakuan, ketergantungan yang dapat diandalkan, bimbingan dan kesempatan untuk mengasuh (Azwan, Herlina \& Karim, 2015).

Berdasarkan pemaparan di atas, peneliti ingin mengetahui kualitas hidup lansia yang ditinjau dari sabar dan dukungan sosial. Adapun hipotesis penelitian, yaitu terdapat hubungan antara sabar dan dukungan sosial dengan kualitas hidup lansia (H1), terdapat hubungan positif antara sabar dan kualitas hidup lansia $(\mathrm{H} 2)$ dan terdapat hubungan positif antara dukungan sosial dan kualitas hidup lansia (H3). 


\section{METODE PENELITIAN}

Populasi dalam penelitian ini adalah lansia dengan usia minimal 60 tahun, baik laki-laki maupun perempuan, beragama Islam dan rutin mengikuti kajian atau pengajian, di kabupaten Sleman, Yogyakarta. Jumlah populasi dalam penelitian ini tidak dapat benarbenar ditentukan, sehingga penentuan ukuran sampel dalam penelitian ini mengikuti definisi sampel dari Sugiyono (2012), yaitu sebagian dari jumlah populasi dengan karakteristik yang sama dengan populasi tersebut. Sampel penelitian ini berjumlah 58 lansia, terdiri atas 34 perempuan dan 24 laki-laki, yang diperoleh melalui teknik purposive sampling, yaitu pengambilan sampel yang didasarkan pada karakteristik atau kriteria yang telah ditentukan sebelumnya (Hadi, 2016).

Metode pengumpulan data dalam penelitian ini menggunakan tiga skala, yaitu skala kualitas hidup, skala sabar dan skala dukungan sosial. Kualitas hidup diukur menggunakan skala World Health Organization Quality of Life (WHOQOL-BREF) berjumlah 26 aitem dengan reliabilitas 0,890, yang meliputi aspek kesehatan fisik, dimensi psikologis, dimensi sosial, dan lingkungan. Sabar diukur menggunakan skala sabar yang modifikasi dari skala sabar (Rusdi, 2016) berjumlah 36 aitem dengan reliabilitas 0,817, yang meliputi aspek sabar dalam menjalankan ketaatan, sabar dalam menjauhi kemaksiatan, dan sabar dalam menghadapi ujian. Dukungan sosial diukur dengan menggunakan skala The Multidimensional Scale of Perceived Social Support (MSPSS) yang disusun oleh Zimet, dkk (1988) berjumlah 12 aitem dengan reliabilitas 0,858 , yang meliputi aspek keluarga, teman, dan orang lain yang dianggap penting.

Analisis data yang digunakan untuk menguji hipotesis penelitian ini adalah analisis regresi berganda, yaitu analisis mengenai hubungan secara linear antara variabel tergantung $(\mathrm{Y})$ dengan dua atau lebih variabel bebas $\left(\mathrm{X}_{1}, \mathrm{X}_{2}, \ldots\right)$ yang harus memenuhi uji normalitas, linearitas, multikolinearitas, heteros-kedastisitas, dan autokorelasi (Priyatno, 2008).

\section{HASIL PENELITIAN}

Deskripsi data penelitian bertujuan untuk mendeskripsikan hasil penelitian agar lebih bermanfaat serta memberikan lebih banyak gambaran tentang data penelitian yang berisi fungsi-fungsi statistik dasar masing-masing variabel untuk skala kualitas hidup, sabar dan dukungan sosial. Deskripsi data tersebut dapat dilihat pada tabel di bawah ini :

Tabel 1.Kategorisasi Tingkat Kualitas Hidup, Sabar, dan Dukungan Sosial

\begin{tabular}{lllllllc}
\hline & \multicolumn{2}{c}{ Kualitas Hidup } & \multicolumn{2}{c}{ Sabar } & \multicolumn{2}{c}{ Dukungan Sosial } \\
\cline { 2 - 7 } & \multicolumn{1}{c}{$\mathbf{F}$} & $\mathbf{\%}$ & $\mathbf{F}$ & $\mathbf{\%}$ & $\mathbf{F}$ & $\mathbf{\%}$ \\
\hline Sangat Rendah & 11 & 19 & 11 & 19 & 10 & 17 \\
Rendah & 10 & 17 & 10 & 17 & 10 & 17 \\
Sedang & 13 & 22 & 12 & 21 & 12 & 21 \\
Tinggi & 14 & 24 & 17 & 29 & 17 & 29 \\
Sangat Tinggi & 10 & 17 & 8 & 14 & 9 & 15,5 \\
\hline
\end{tabular}


Hasil uji normalitas menunjukan bahwa data dari ketiga variabel penelitian yaitu kualitas hidup, sabar dan dukungan sosial berdistribusi normal. Hal ini dilihat dari nilai signifikansi sebesar 0,200, 0,080 dan 0,200 ( $p>0,05)$. Hasil uji linearitas menunjukkan bahwa terdapat hubungan yang linear antara kualitas hidup dan sabar $(p<0,05)$ serta antara kualitas hidup dan dukungan sosial $(p<0,05)$.

Hasil uji multikolinearitas antara sabar dan dukungan sosial sebesar 0,130 ( $\mathrm{r}<0,85)$ menunjukkan bahwa antara variabel bebas tidak terjadi multikolinealiritas. Hasil ujiheteroskedastisitas dengan scatterplot diketahui bahwa titik-titik menyebar pada sumbu Y dan tidak membentuk pola tertentu. Hal ini menunjukkan bahwa tidak terjadi heteroskedastisitas. Hasil uji autokorelasi menunjukkan bahwa nilai DW sebesar 1,853 dan berada diantara dU dan 4-dU $(1,6475<1,853<2,3525)$ menunjukkan bahwa tidak terjadi autokorelasi. Data penelitian ini memenuhi uji prasyarat untuk dilakukannya analisis regresi berganda.

Hasil uji regresi berganda menunjukkan nilai $\mathrm{F}=13,344$ dengan signifikansi 0,000 ( $p<$ $0,05)$. Hal ini menunjukkan bahwa terdapat hubungan positif dan signifikan antara sabar dan dukungan sosial terhadap kualitas hidup lansia. Dengan demikian, hipotesis pertama (H1) diterima.

Tabel 2.Hasil Uji Hipotesis

\begin{tabular}{lcccccc}
\hline & Model & $\mathrm{R}$ & $\mathrm{R}^{2}$ & Adjusted R $^{2}$ & $\mathrm{~F}$ & Sig. \\
\hline Sabar dan Dukungan Sosial & 1 & 0,437 & 0,191 & 0,177 & 13.344 & 0,000 \\
terhadap Kualitas Hidup & 2 & 0,572 & 0,327 & 0,302 & & \\
\hline
\end{tabular}

Berdasarkan tabel di atas, diketahui bahwa terjadi hubungan yang sedang antara sabar dan dukungan sosial terhadap kualitas hidup $(R=0,572)$. Besarnya sumbangan efektif sabar dan dukungan sosial terhadap kualitas hidup sebesar $32,7 \%\left(R^{2}=0,327\right)$, dengan kata lain, sabar dan dukungan sosial mampu memprediksi kualitas hidup sebesar 32,7\%.

Uji korelasi parsial yang dilakukan untuk mengetahui hubungan antara dua variabel dengan mengendalikan variabel lainnya yang dianggap berpengaruh (Priyatno, 2008). Hasil uji korelasi parsial menunjukkan bahwa terdapat hubungan yang positif dan signifikan antara sabar dan kualitas hidup pada lansia $(p<0.05)$ dan terdapat hubungan yang positif dan signifikan antara dukungan sosial dan kualitas hidup lansia $(p<0,05)$. Dengan demikian, hipotesis kedua (H2) dan hipotesis ketiga (H3) diterima.

Tabel 4. Hasil Uji Hipotesis H2 dan H3

\begin{tabular}{lcc}
\hline & $\mathrm{r}$ & Sig. \\
\hline Sabar dan Kualitas Hidup & 0,425 & 0,001 \\
Dukungan Sosial dan Kualitas Hidup & 0,409 & 0,002 \\
\hline
\end{tabular}

\section{DISKUSI}

Tujuan dari penelitian ini adalah untuk mengetahui hubungan sabar dan dukungan sosial terhadap kualitas hidup lansia yang mengikuti kegiatan pengajian di kabupaten Sleman, Yogyakarta. Hasil analisis data yang dilakukan menunjukkan bahwa terdapat hubungan yang positif dan signifikan antara sabar dan dukungan sosial terhadap kualitas hidup pada 
lansia, dengan demikian hipotesis pertama dalam penelitian ini diterima. Sabar dan dukungan sosial secara bersama-sama berpengaruh terhadap kualitas hidup lansia. Semakin tinggi kesabaran lansia dan semakin tinggi dukungan sosial yang diperoleh lansia, maka semakin tinggi pula kualitas hidupnya. Sumbangan efektif dari sabar dan dukungan sosial terhadap kualitas hidup sebesar 32,7\%, sedangkan 67,3\% dipengaruhi oleh variabel lain yang tidak diteliti dalam penelitian ini.

Hasil uji korelasi parsial antara sabar dan kualitas hidup menunjukkan bahwa terdapat hubungan yang positif dan signifikan antara sabar dan kualitas hidup $(\mathrm{r}=0,425, p<0,05)$ dengan sumbangan efektif sabar sebesar 19,1\%. Hasil uji korelasi parsial antara dukungan sosial dan kualitas hidup juga menunjukkan bahwa terdapat hubungan yang positif dan signifikan antara dukungan sosial dan kualitas hidup ( $\mathrm{r}=0,409, p<0,05)$ dengan sumbangan efektif dukungan sosial sebesar 13,6\%. Dengan demikian, hipotesis kedua $(\mathrm{H} 2)$ dan ketiga $(\mathrm{H} 3)$ diterima.

Kualitas hidup pada lansia menggambarkan kesejahteraan dan kepuasan terhadap hidup yang dijalaninya (Abeles, Gift, \& Ory, 1994). Berdasarkan hasil penelitian, diketahui bahwa sebagian besar tingkat kualitas hidup pada lansia berada pada rentang sedang tinggi. Lansia yang memiliki tingkat kualitas hidup yang sedang sampai tinggi berarti merasakan kesejahteraan dan kepuasan dalam hidupnya yang meliputi aspek kesehatan fisik, kondisi psikologis, kondisi sosial, dan lingkungan. Kesejahteraan dan kepuasan hidup dapat diperoleh oleh lansia ketika lansia mampu menghadapi berbagai keadaan yang menimbulkan stres, seperti perubahan fisik yang dialami, mudah terserang penyakit, kehilangan pasangan, dan jauh dari anak dan anggota keluarga yang lain. Hal ini sesuai dengan Azizah dan Hartanti (2016) yang menyatakan bahwa tingkat stres yang meningkat dapat menurunkan kualitas hidup lansia, begitu pula sebaliknya, lansia dengan tingkat stres yang rendah akan memiliki kualitas hidup yang meningkat.

Sabar merupakan salah satu strategi koping yang dapat diterapkan untuk menurunkan tingkat stres pada lansia, sehingga kualitas hidup lansia dapat meningkat. Hasil penelitian ini menunjukkan bahwa sabar berkorelasi positif dengan kualitas hidup lansia, yaitu semakin tinggi tingkat kesabaran lansia, semakin tinggi pula kualitas hidup lansia. Hal ini sesuai dengan Safitri dan Kumolohadi (2008) yang menyatakan bahwa tingkat kesabaran berpengaruh terhadap penurunan stres, sehingga kualitas hidup lansia dapat meningkat. Lansia yang bersabar dalam menjalani hidupnya dan terhadap takdir Allah akan merasakan kesejahteraan dan tidak mudah stres, sehingga hal ini dapat meningkatkan kualitas hidupnya, seperti firman Allah SWT dalam surat Al-Baqarah ayat 155-157 yang artinya,

"Berikan kabar gembira kepada orang-orang yang sabar, yaitu orangorang yang jika ditimpa suatu musibah berkata, "Sesungguhnya kita ini milik Allah, dan kepadaNyalah kita kembali." Merekalah orang-orang yang mendapat salam kesejahteraan dan rahmat dari Rabb mereka. Dan merekalah orang-orang yang mendapatkan petunjuk."

Sabar juga termasuk satu strategi koping religius karena melibatkan kepercayaan kepada agama untuk mengatasi kondisi stres, salah satunya yaitu keyakinan kepada Allah (Pargament, dkk, dalam Gardner, Krägeloh, \& Henning, 2013). Koping religius memiliki korelasi negatif dengan tingkat stres dan berkorelasi positif dengan kualitas hidup, yaitu 
koping religius dapat menurunkan tingkat stres pada individu dan meningkatkan kualitas hidupnya (Gardner, Krägeloh, \& Henning, 2013). Hal ini didukung oleh Jurniarly dan Hadjam (2012) yang menyatakan bahwa koping religius merupakan salah satu cara terbaik untuk menurunkan tingkat stres dan depresi.

Sabar tidak hanya menurunkan tingkat stres pada individu, tetapi sabar juga dapat menurunkan emosi negatif seperti kecemasan. Dipoalam dan Uyun (2008) mengungkapkan bahwa semakin tinggi tingkat kesabaran, maka akan semakin rendah kecemasan yang dirasakan individu. Sabar juga berpengaruh terhadap kepuasan pernikahan seperti yang diungkapkan Kumala dan Trihandayani (2015) bahwa pasangan yang sabar dapat bertahan menghadapi masalah dan secara aktif mencari alternatif solusi yang tepat, sehingga hal ini menjadikan pasangan lebih bahagia. Rendahnya tingkat kecemasan yang dialami individu dan adanya kepuasan pernikahan yang dirasakan, dapat meningkatkan kesejahteraan individu yang berpengaruh terhadap meningkatnya kualitas hidup. Hal ini sesuai dengan Schnitker (2012) bahwa kesabaran mempengaruhi kesejahteraan (well being), yang meliputi memaksimalkan kesenangan atau kebahagiaan dan meminimalkan emosi negatif (Ryan \& Deci dalam Schnitker, 2012). Kesabaran merupakan penyangga terhadap emosi dalam situasi stres yang memungkinkan individu lebih adaptif dalam mengatasi frustrasi dan memfasilitasi interaksi interpersonal yang positif (Schnitker, 2012).

Berbagai perubahan yang dialami lansia, seperti penurunan fungsi fisik, psikologis, dan sosial menimbulkan kesulitan pada lansia untuk beraktivitas, merawat diri, berinteraksi, dan keterbatasan yang lain. Rohmah, Purwaningsih, \& Bariyah (2012) menyatakan bahwa penurunan fungsi fisik menyebabkan lansia memiliki keterbatasan fisik yang menghambat pencapaian kesejahteraan fisik. Oleh karena itu, lansia membutuhkan dukungan sosial dari lingkungannya, terutama keluarga dan lingkungan sekitar. Hasil penelitian ini menunjukkan bahwa dukungan sosial berkorelasi positif dengan kualitas hidup lansia, yaitu semakin tinggi tingkat dukungan sosial yang diterima lansia, semakin tinggi pula kualitas hidup lansia. Dukungan sosial yang diterima oleh lansia akan membuat lansia merasa diperhatikan, disayang, dihargai, diterima, dan dipedulikan. Perasaan-perasaan yang dirasakan oleh lansia karena adanya dukungan sosial akan membuat lansia merasakan kesejahteraan, sehingga dapat meningkatkan kualitas hidupnya (Sarafino \& Smith, 2011). Hal ini didukung oleh Antari, Saktika, dan Ferianto (2016) yang mengungkapkan bahwa dukungan sosial yang diterima oleh lansia akan meningkatkan kualitas hidup lansia karena dukungan sosial yang diterima dapat mengurangi stres yang dirasakan oleh lansia.

Dukungan sosial akan menciptakan lingkungan kondusif yang mampu memberikan motivasi bagi lansia dalam menjalani kehidupannya karena dukungan sosial dapat meminimalkan tekanan psikososial yang dirasakan oleh lansia (Sarafino \& Smith, 2011). Hal ini didukung oleh Azwan, Herlina, dan Karim (2015) yang mengungkapkan bahwa dukungan sosial akan meningkatkan interaksi serta saling memberikan dukungan antar lansia. Noviarini, Dewi dan Prabowo (2013) juga mengungkapkan bahwa adanya dukungan sosial pada individu yang mendapatkan masalah dan tekanan dapat membantu individu tersebut untuk dapat mengatasi masalah yang dialami dan dapat meningkatkan kualitas hidupnya. 
Berdasarkan uraian di atas, dapat diketahui bahwa kualitas hidup lansia dapat dipengaruhi oleh faktor internal dan faktor eksternal.Faktor internal, salah satunya adalah sabar dan faktor eksternal, salah satunya adalah dukungan sosial. Ketika lansia mampu bersabar dalam menghadapi berbagai perubahan yang disebabkan oleh penurunan fungsi fisik, psikologis, dan sosial, serta memperoleh dukungan sosial dari keluarga, teman, maupun lingkungan masyarakat, maka lansia tersebut akan dapat mempertahankan kualitas hidupnya dan meningkatkan kualitas hidupnya ke arah yang positif.

Keterbatasan pada penelitian ini, yaitu hasil penelitian tidak dapat digeneralisasikan karena sampel yang digunakan kurang representatif. Selain itu, alat ukur yang digunakan cukup sulit untuk dipahami dikarenakan dalam mengadaptasi alat ukur tersebut kurang mempertimbangkan subjek penelitian.

\section{SIMPULAN DAN IMPLIKASI}

Berdasarkan hasil penelitian dapat disimpulkan bahwa terdapat hubungan positif yang signifikan antara sabar dan dukungan sosial terhadap kualitas hidup pada lansia, artinya sabar dan dukungan sosial berpengaruh pada kualitas hidup pada lansia.

Bagi lansia, yaitu memperbanyak interaksi dengan teman-teman sebaya, terlibat dalam berbagai kegiatan sosial, berusaha menceritakan permasalahan yang dihadapi kepada keluarga, dan berusaha untuk selalu bersabar menghadapi berbagai macam ujian dan permasalahan hidup. Bagi keluarga, yaitu memberikan perhatian yang lebih kepada lansia, berusaha untuk mendengarkan keluh kesah maupun permasalahan lansia, dan meluangkan waktu untuk mengajak lansia menikmati kebersamaan. Bagi takmir masjid, yaitu mengadakan kegiatan yang khusus untuk lansia, seperti pengajian khusus lansia dan mengadakan kajian terkait pentingnya kesabaran dalam kehidupan. Bagi peneliti selanjutnya, dapat mengembangkan konsep sabar untuk melihat pengaruhnya terhadap kualitas hidup.

\section{REFERENSI}

Abeles, R., Gift, H., \& Ory, M. (1994). Aging and Quality of Life. New York : Springer Publishing Company.

Al-Jauziyah, I. (2006). Kemuliaan Sabar dan Keagungan Syukur. Yogyakarta: Mitra Pustaka.

Antari, B., Saktika, T., \& Ferianto. (2016). Hubungan antara dukungan sosial dengan kualitas hidup lansia di desa Cebongan Sleman Yogyakarta tahun 2015.Media Ilmu Kesehatan, 5 (1).

Azizah, R. \& Hartanti, R.D. (2016). Hubungan antara tingkat stres dengan kualitas hidup lansia hipertensi di wilayah kerja puskesmas Wonopringgo, Pekalongan.The $4^{\text {th }}$ University Research Coloqouium 2016. 
Azwan, Herlina, \& Karim, D. (2015). Hubungan dukungan sosial teman sebaya dengan kualitas hidup lansia di panti sosial Tresna Werdha. JOM, 2 (2), 262-270.

Badan Pusat Statistik. (2016). Statistik Penduduk Lanjut Usia 2015. Jakarta: Badan Pusat Statistik.

Bowling, A. (2003). Current state of the art in quality of life measurement.In Allison J. Carr, Irene J. Higginson, \& Peter G. Robinson eds. Quality of life. London: BMJ Books.

Dipoalam, M. \& Uyun, Q. (2008). Hubungan antara Kesabaran dengan Tingkat Kecemasan pada Mahasiswa. (skripsi tidak dipublikasikan). Universitas Islam Indonesia. Yogyakarta.

Desmita. (2010). Psikologi Perkembangan (edisi keenam). Bandung : PT Remaja Rosdakarya.

Gardner, T., Krägeloh, C., Henning, M. (2013). Religious coping, stress, and quality of life of Muslim university students in New Zealand. Mental Health, Religion \& Culture.

Hadi, S. (2016). Metodologi Riset. Yogyakarta : Pustaka Pelajar

Hurlock, E.B. (2006). Psikologi Perkembangan: Suatu Pendekatan Sepanjang Rentang Kehidupan (edisi kelima). Jakarta : Penerbit Erlangga.

Jhonson, D.W. \& Jhonson, F.P. (1991). Joining Together: Group theory and group skills. Fourth Edition. London : Prentice Hall International.

Jurniarly, A. \& Hadjam, M. (2012). Peran koping religius dan kesejahteraan subjektif terhadap stres pada anggota bintara polisi di polres kebumen.Psikologika, 17 (1).

Kumala, A., \& Trihandayani, D. (2015). Peran Memaafkan dan Sabar dalam Menciptakan Kepuasan Perkawinan. Jurnal Ilmiah Penelitian Psikologi: Kajian Empiris \& Non-Empiris, Vol. 1 (1), 39-44

Noviarini, NA., Dewi, MP., Prabowo, H. (2013). Hubungan antara dukungan sosial dan kualitas hidup pada pecandu narkoba yang sedang menjalani rehabilitasi : Proceeeding PESAT Vol 5

Priyatno, D. (2008). Mandiri Belajar SPSS. Yogyakarta: MediaKom.

Rohmah, A.I., Purwaningsih, Bariyah, K. (2012). Kualitas hidup lanjut usia. Fakultas Ilmu Kesehatan Universitas Muhammadiyah Malang : Jurnal Keperawatan, 3 (2), 120-132.

Rubbyana, U. (2012). Hubungan antara strategi koping dengan kualitas hidup pada penderita skizofrenia remisi simptom.Jurnal Psikologi Klinis dan Kesehatan Mental, 1 (02), 59-66.

Rusdi, A. (2016). Patience in islamic psychology and its measurement. Paper Conference for the $3^{\text {rd }}$ Inter-Islamic University Conference on Psychology. 
Safitri, A. \& Kumolohadi, RA. (2008). Hubungan antara kesabaran dengan stres menghadapi ujian pada mahasiswa. Naskah publikasi. Yogyakarta: Universitas Islam Indonesia.

Santrock, J. (2010). Life-Span Development $13^{\text {th }}$ ed.). New York : McGraw-Hill.

Sarafino, E., \& Smith, T. (2011). Health Psychology: Biopsychosocial Interactions $\left(7^{\text {th }}\right.$ ed.). USA: John Wiley \& Sons, Inc.

Schnitker, S. A. (2012). An examination of patience and well being. The Journal of Positive Psychology, 7 (4), 263-280.

Sugiyono. (2012). Metode Penelitian Kuantitatif, Kualitatif, dan $R$ \& D. Bandung: ALFABETA.

World Health Organization (WHO). (1997). WHOQOL Measuring Quality of Life. Division of Mental Health and Prevention of Substance Abuse. 97(4).

Zimet, G. D., Dahlem, N. W., Zimet, S. G., \& Farley, G. K. (1988). The Multidimensional Scale of Perceived Social Support. Journal of Personality Assessment, 52(1), 30-41 